\title{
PENGARUH KOMITMEN ORGANISASIONAL TERHADAP ORGANIZATIONAL CITIZENSHIP BEHAVIOUR DENGAN KEPUASAN KERJA SEBAGAI VARIABEL PEMODERASI
}

\author{
Ni Kadek Ryan Krisjayanti ${ }^{1}$ \\ Wayan Gede Supartha ${ }^{2}$ \\ ${ }^{1,2}$ Fakultas Ekonomi dan Bisnis, Universitas Udayana, Bali-Indonesia \\ email: kadekryankrisjayanti1998@gmail.com
}

\begin{abstract}
ABSTRAK
Penelitian ini bertujuan untuk menyelidiki peran moderasi dari kepuasan kerja pada pengaruh komitmen organisasi terhadap Organizational Citizenship Behaviour (OCB). Lokasi penelitian dipilih di Dinas Sosial Kota Denpasar. Teknik analisis data yang digunakan adalah Moderated Regression Analysis (MRA). Berdasarkan hasil analisis yang dilakukan, didapatkan hasil bahwa komitmen organisasional berpengaruh signifikan pada OCB. Demikian juga pada variabel kepuasan kerja berpengaruh pada OCB pada pegawai Dinas Sosial Kota Denpasar. Kepuasan kerja memperkuat pengaruh komitmen organisasi pada OCB. Hasil penelitian ini memberikan sebuah implikasi teoritis bagaimana pentingnya komitmen organisasional dan kepuasan kerja dapat mempengaruhi Organizational Citizenship Behaviour (OCB).
\end{abstract}

Kata Kunci: Komitmen organisasi, organizational citizenship behavior, kepuasan kerja.

\begin{abstract}
This study aims to investigate the role of moderation of job satisfaction on the effect of organizational commitment on Organizational Citizenship Behavior (OCB). The research location was chosen at the Denpasar Social Service. The data analysis technique used Moderated Regression Analysis (MRA). Based on the results of the analysis conducted, it was found that organizational commitment had a significant effect on OCB. Likewise, the variable of job satisfaction has an effect on OCB on Denpasar Social Service employees. Job satisfaction reinforces the effect of organizational commitment on OCB. The results of this study provide a theoretical implication of how the importance of organizational commitment and job satisfaction can affect Organizational Citizenship Behavior (OCB).

Keywords: Organizational commitment, organizational citizenship behavior, job satisfaction.
\end{abstract}


Ni Kadek Ryan Krisjayanti, Pengaruh Komitmen Organisasional...

\section{PENDAHULUAN}

Sumber daya manusia merupakan salah satu faktor yang dapat menciptakan identitas didalam organisasi, dan dapat menghasilkan keuntungan yang lebih bagi organisasi (Erkutlu, 2011). Sumber daya manusia harus dikelola dengan baik guna meningkatkan efektifitas dan keberhasilan sebuah organisasi, untuk itu organisasi harus memiliki sumber daya manusia yang disiplin, professional, bertanggung jawab dan beintegritas tinggi kepada organisasinya (Prameswari \& Suwandana, 2017). Sumber daya manusia merupakan sumber daya yang penting, karena dengan adanya sumber daya manusia, maka sumber daya lain dalam organisasi dapat berfungsi atau dijalakankan dengan baik (Rivai \& Sagala, 2011). Organizational Citizenship Behaviour (OCB), yaitu perilaku melebihi apa yang telah distandarkan organisasi dan dapat mendukung peningkatan kinerja SDM (Krietner \& Kinicki, 2004).

Menurut Andriani et al. (2012), Organizational Citizenship Behaviour (OCB) merupakan perilaku yang timbul atas dasar keinginan seorang pegawai yang ingin mengerjakan sesuatu secara sukarela tanpa adanya paksaan dari pihak manapun. Organizational Citizenship Behaviour (OCB) merupakan prilaku pegawai yang tidak hanya mengerjakan tugas pokoknya saja namun bersedia melakukan tugas tambahan seperti mau bekerja sama, membantu rekan kerja, serta mau menggunakan waktu kerjanya dengan efektif tanpa imbalan apapun untuk membantu organisasi berhasil mencapai tujuannya (Nugraha dan Dewi, 2018). Seseorang dengan perilaku Organizational Citizenship Behaviour (OCB) yang tinggi rela tidak dibayar dalam bentuk uang atau bonus tertentu, tetapi lebih kepada perilaku sosial dari masing-masing pegawai untuk bekerja melebihi apa yang diharapkan oleh organisasi (Ahdiyana, 2013).

Kinerja di dalam organisasi dapat berjalan dengan baik apabila pegawai yang ada di dalam organisasi berperilaku positif seperti, saling menguatkan, saling membantu, dan saling mengisi, sehingga perilaku Organizational Citizenship Behaviour (OCB) ini dapat menimbulkan suasana yang kondusif di dalam organisasi (Aswin \& Rahyuda, 2017). Organizational Citizenship Behaviour (OCB) dapat memberikan peningkatan pada produktivitas rekan kerja, peningkatan produktivitas manajer, dan menghemat sumber daya yang dimiliki organisasi secara keseluruhan (Podsakoff et al., 2020). Lovell (1999) berpendapat bahwa Organizational Citizenship Behaviour (OCB) merupakan perilaku pegawai yang melebihi dari perilaku yang disyaratkan oleh organisasi yang terdapat dalam suatu deskripsi pekerjaan yang formal (formal job description).

Penelitian ini dilakukan di Dinas Sosial Kota Denpasar. Dinas Sosial Kota Denpasar merupakan instansi pemerintah yang memberikan pelayanan kesejahteraan masyarakat seperti penyaluran dana bantuan terhadap masyarakat yang kurang mampu di Kota Denpasar. Salah satu tujuan dari Dinas Sosial Kota Denpasar adalah meningkatkan kualitas hidup bagi masyarakat Kota Denpasar 
yang kurang mampu dengan jumlah pegawai 127 orang diantaranya 90 orang pegawai kontrak dan 37 orang pegawai tetap yang dapat dilihat pada Tabel 1.

Tabel 1.

Data Jumlah dan Klasifikasi Pangkat Pegawai Tetap Dinas Sosial Kota Denpasar Tahun 2019

\begin{tabular}{cllc}
\hline \multirow{2}{*}{ No } & Golongan & \multicolumn{1}{c}{ Jenis Pangkat } & $\begin{array}{c}\text { Jumlah } \\
\text { Pegawai }\end{array}$ \\
\hline 1 & II/b & Pangkat Pengatur Muda Tingkat I & 1 \\
& II/c & Pangkat Pengatur & 5 \\
& II/d & Pangkat Pengatur Tingkat I & 1 \\
2 & III/a & Pangkat Penata Muda & 2 \\
& III/b & Pangkat Penata Muda Tingkat I & 3 \\
& III/c & Pangkat Penata & 6 \\
3 & III/d & Pangkat Penata Tingkat I & 9 \\
& IV/a & Pangkat Pembina & 7 \\
& IV/b & Pangkat Pembina Tingkat I & 2 \\
Jumlah & IV/c & Pangkat Pembina Utama Muda & 1 \\
\hline
\end{tabular}

Sumber: Data Diolah, 2020

Tabel 1. menunjukkan bahwa dari 37 orang pegawai tetap terdapat 10 orang berada pada golongan IV, 20 orang yang berada pada golongan III, dan 6 orang yang berada pada golongan II. Sedangkan 90 pegawai lainnya merupakan pegawai kontrak yang belum dikualifikasikan dalam kepangkatan pegawai. Pegawai kontrak hanya diberikan tugas tertentu pada bidangnya masing - masing dalam membantu kinerja Dinas Sosial Kota Denpasar.

Hasil wawancara dengan Kepala Bidang Kepegawaian pada Dinas Sosial Kota Denpasar terdapat masalah yang berkaitan dengan perilaku Organizational Citizenship Behaviour (OCB) yang belum maksimal, yaitu masih adanya pegawai yang tidak mematuhi peraturan serta belum memiliki keinginan untuk saling membantu rekan kerja dan hanya mengerjakan tugasnya itu sendiri (altruism), masih adanya pegawai yang meninggalkan pekerjaannya saat jam kerja masih berlangsung dan terdapat beberapa karyawan yang tidak ikut berkontribusi dan menyalurkan ide-ide (civic virtue), dan pegawai harus diperintahkan untuk melakukan pekerjaan tanpa adanya inisiatif dari diri sendiri (conscientiousness), selain itu juga terdapat pegawai yang menyebarkan isu-isu untuk menjatuhkan karyawan lainnya (sportsmanship). Masalah-masalah tersebut apabila tidak diselesaikan dengan baik dapat mempengaruhi kinerja pada organisasi/ instansi, karena dalam instansi yang melakukan pelayanan kepada masyarakat di bidang sosial sangat membutuhkan peran dari sumber daya manusia yang baik. Masalahmasalah yang terjadi pada organisasi tersebut muncul akibat dari karakteristik yang dimiliki oleh masing-masing individu berbeda sehingga inisiatif untuk melakukan pekerjaan maupun membantu rekan kerja tidak sama pada setiap individu, tidak adanya dorongan seperti pegawai tidak memiliki kesempatan yang sama dalam jenjang karir. 
Pra-Survei dilakukan dengan menyebar kuisioner kepada 10 responden pegawai Dinas Sosial Kota Denpasar. Tabel 2. menyatakan bahwa belum maksimalnya keinginan pada pegawai untuk membantu rekan kerja dengan sukarela tanpa menerima imbalan pada Dinas Sosial Kota Denpasar hal ini dapat dilihat dari responden yang menjawab "setuju" belum seratus persen. Dari hal tersebut, maka perlu dilakukan penelitian mengenai faktor-faktor yang menjadi penyebab belum maksimalnya OCB pada pegawai Dinas Sosial Kota Denpasar.

Tabel 2.

Persentase (\%) Jawaban Responden Pra- Survei Data Organizational Citizenship Behaviour pegawai Dinas Sosial Kota Denpasar

\begin{tabular}{|c|c|c|c|c|c|c|}
\hline & Pernyataan & STS & TS & KS & $\mathbf{S}$ & SS \\
\hline 1. & $\begin{array}{l}\text { Saya bersedia menolong rekan kerja yang } \\
\text { memiliki kesulitan dalam menangani tugas }\end{array}$ & - & 20 & 30 & 40 & 10 \\
\hline 2. & $\begin{array}{l}\text { Saya senang membantu rekan kerja saya } \\
\text { dengan sukarela tanpa mengharapkan } \\
\text { imbalan }\end{array}$ & - & 10 & 20 & 60 & 20 \\
\hline 3. & $\begin{array}{l}\text { Saya ikut berpartisipasi dalam setiap } \\
\text { kegiatan yang diadakan perusahaan }\end{array}$ & - & 20 & 20 & 50 & 10 \\
\hline 4. & $\begin{array}{l}\text { Saya bersedia melaksanakan tugas yang } \\
\text { melebihi standar pencapaian }\end{array}$ & - & 20 & 20 & 40 & 10 \\
\hline 5. & $\begin{array}{l}\text { Saya membantu meringankan masalah- } \\
\text { masalah yang berkaitan dengan pekerjaan } \\
\text { yang dihadapi rekan kerja saya }\end{array}$ & - & 10 & 20 & 50 & 20 \\
\hline 6. & $\begin{array}{l}\text { Saya tidak memberikan isu-isu yang dapat } \\
\text { menjatuhkan karyawan lain }\end{array}$ & - & 30 & 20 & 40 & 10 \\
\hline
\end{tabular}

Sumber: Data Diolah, 2020

$$
\begin{aligned}
\text { Keterangan : } & \text { STS }=\text { Sangat Tidak Setuju } \\
\text { TS } & =\text { Tidak Setuju } \\
\text { KS } & =\text { Cukup Setuju } \\
\text { S } & =\text { Setuju } \\
\text { SS } & =\text { Sangat Setuju }
\end{aligned}
$$

Menurut Ratnaningsih (2013), rendahnya Organizational Citizenship Behaviour (OCB) dapat disebabkan oleh rendahnya kepuasan kerja dan komitmen organisasional. Menurut hasil wawancara terhadap beberapa pegawai Dinas Sosial Kota Denpasar yang dilakukan peneliti, mengindikasikan bahwa pegawai menunjukkan rendahnya kepuasan kerja di Dinas Sosial Kota Denpasar, hal ini dapat ditinjau dari sikap pegawai Dinas Sosial Kota Denpasar yang merasa pekerjaannya cenderung membosankan karena hanya akan mengerjakan satu jenis pekerjaan yang merupakan job description dari posisinya dan juga kurangnya apresiasi dari pimpinan terhadap kinerja mereka. Selain menunjukkan indikasi rendahnya kepuasan kerja, pegawai Dinas Sosial Kota Denpasar juga menunjukkan indikasi rendahnya komitmen organisasional di Dinas Sosial Kota Denpasar, hal ini dapat ditinjau dari sikap pegawai yang memiliki hubungan emosional yang rendah dengan organisasi. 
Dinas Sosial Kota Denpasar harus mengembangkan sikap Organizational Citizenship Behaviour (OCB) sebagai prilaku di luar persyaratan formal pekerjaan agar dapat terus berkembang dan mencapai tujuan serta memberikan keuntungan bagi organisasi. Hal ini akan mendorong pegawai untuk melakukan hal lebih diluar pekerjaannya. Pegawai yang menunjukkan perilaku tersebut akan memberikan kontribusi positif terhadap organisasi melalui perilaku di luar uraian tugas, di samping pegawai tetap melaksanakan tanggung jawab sesuai pekerjaannya.

Pegawai yang berkomitmen cenderung lebih bertanggungjawab dalam memberikan pelayanan pada saat bekerja (Ping et al., 2012). Pegawai akan memiliki komitmen organisasional yang tinggi ketika merasa puas dengan pekerjaan, supervisi, gaji, promosi dan rekan kerja (Harrison dan Hubbard, 1998). Komitmen organisasional menimbulkan dorongan dari dalam diri inidividu untuk berbuat suatu agar dapat menunjang keberhasilan organisasi sesuai dengan tujuan dari organisasi dan meletakkan kepentingan organisasi diatas kepentingan pribadi (Wiener, 1982).

Menurut Griffin \& Ebert, (1996) pegawai yang memiliki kepuasan dalam bekerja, maka pegawai akan cenderung berkomitmen dan setia di tempatnya bekerja karena merasa lebih diperhatikan oleh organisasi. Menurut Griffin (2004), komitmen organisasional adalah sikap yang mencerminkan sejauh mana seseorang individu dapat mengenal dan terikat pada organisasinya. Seorang pegawai akan bertanggung jawab dan berupaya bekerja semaksimal mungkin dengan kemampuan yang dimiliknya apabila pegawai tersebut merasakan kepuasan terhadap pekerjaannya (Yanti \& Supartha, 2017).

Pegawai yang merasa puas akan berbicara positif tentang organisasinya, membantu individu lain, dan mampu menyelesaikan pekerjaan mereka melebihi yang diharapkan, sehingga berdampak positif terhadap organisasi (Robbins 2015). Menurut Anas (2013), apabila kepuasan kerja pegawai terjaga, maka akan mengakibatkan semangat kerja yang tinggi dan dapat membantu pihak organisasi dalam mencapai tujuan yang diinginkan organisasi. Menurut Griffin \& Ebert, (1996) pegawai yang memiliki kepuasan dalam bekerja, maka pegawai akan cenderung berkomitmen dan setia di tempatnya bekerja karena merasa lebih diperhatikan oleh organisasi. Menurut Robbins, (2015:53) menyatakan bahwa kepuasan kerja berkorelasi moderat dengan OCB. Individu yang merasa puas dengan pekerjaan mereka akan lebih terlibat dalam Organizational Citizenship Behaviour (OCB).

Penelitian ini bertujuan untuk menyelidiki peran moderasi dari kepuasan kerja pada pengaruh komitmen organisasi terhadap Organizational Citizenship Behaviour (OCB).

Menurut Woolfolk (2009) teori sosial kognitif adalah sebuah teori yang memberikan pemahaman, prediksi, dan perubahan perilaku manusia melalui interaksi antara manusia, perilaku, dan lingkungan. Teori ini didasarkan atas proposisi bahwa baik proses sosial maupun proses kognitif adalah sentral bagi pemahaman mengenai motivasi, emosi, dan tindakan manusia. Menurut Bandura (1986), dalam teori kognitif berkaitan dengan teori agensi manusia yang 
Ni Kadek Ryan Krisjayanti, Pengaruh Komitmen Organisasional...

merupakan teori psikolog yang memainkan peran aktif dalam proses pengembangan diri mereka.

Teori sosial kognitif digunakan untuk mengenal, memprediksi perilaku dan mengidentifikasi metode-metode yang tepat untuk mengubah perilaku tersebut. Teori ini menjelaskan bahwa dalam belajar, pengetahuan (knowledge), pengalaman pribadi (personal experience), dan karakteristik individu (personal characteristic) saling berinteraksi. Dalam hal lainnya Mischel dan teman-teman nya memperluas pandangan teoritis dengan memberikan penjelasan tentang bagaimana variabel-variabel dapat dipahami sebagai suatu sistem kognitif dan afektif yang saling terkait yang mendasari individualitas manusia (Mischel and Soda, 1995).

Penelitian yang dilaksanakan oleh Bakan et al., (2013), menemukan bahwa ada hubungan yang signifikan antara komitmen organisasional dan Organizational Citizenship Behaviour (OCB). Penelitian yang dilaksanakan oleh Anshori (2013) menemukan bahwa adanya hubungan antara komitmen organisasional dengan Organizational Citizenship Behaviour (OCB). Parnell dan Crandall (2003) juga menyarankan bahwa pegawai dengan komitmen organisasional yang tinggi cenderung menunjukkan Organizational Citizenship Behaviour (OCB). Sebuah penelitian oleh Feather dan Rauter (2004), menemukan bahwa komitmen organisasional memiliki dampak positif yang signifikan padaOrganizational Citizenship Behaviour (OCB). O'Reilly \& Chatman (1986), menemukan bahwa komitmen organisasi secara positif mempengaruhi Organizational Citizenship Behaviour (OCB).

$\mathrm{H}_{1}$ : Komitmen organisasional berpengaruh positif dan signifikan terhadap organizational citizenship behaviour (OCB)

Penelitian yang dilakukan oleh Rohayati (2014) menyatakan bahwa variabel kepuasan kerja berpengaruh positif dan signifikan terhadap Organizational Citizenship Behaviour (OCB). Hal ini berarti bahwa tinggi rendahnya Organizational Citizenship Behaviour (OCB) sebagai akibat dari tinggi rendahnya kualitas kepuasan kerja yang berjalan. Hasil yang sama juga ditunjukkan oleh penelitian yang dilakukan oleh Kencanawati (2014) menyatakan bahwa kepuasan kerja berpengaruh signifikan terhadap Organizational Citizenship Behaviour (OCB). Penelitian yang dilakukan oleh Lu et al., (2013); Sharma \& Bajpai (2011) menunjukkan bahwa kepuasan kerja berpengaruh positif terhadap Organizational Citizenship Behaviour (OCB). Penelitian yang dilakukan oleh Chiboiwa et al. (2011) menghasilkan temuan bahwa kepuasan kerja secara signifikan berdampak positif terhadap Organizational Citizenship Behaviour (OCB). Fatimah \& Halim (2011) dalam penelitiannya pada guru-guru sekolah menengah di Selangor Malaysia membuktikan terdapat hubungan yang positif dan signifikan terhadap OCB.

$\mathrm{H}_{2}$ : Kepuasan kerja berpengaruh positif dan signifikan terhadap organizational citizenship behaviour (OCB).

Hasil Penelitian menunjukkan bahwa kepuasan kerja berhubungan positif dengan Organizational Citizenship Behaviour (OCB) (Bateman \& Organ, 1983). Schappe (1998), juga menemukan bahwa kepuasan kerja secara positif 
mempengaruhi Organizational Citizenship Behaviour (OCB). Kuehn \& AlBusaidi (2002), melaporkan bahwa kepuasan kerja dan komitmen normatif positif mempengaruhi Organizational Citizenship Behaviour (OCB). Kepuasan kerja memiliki pengaruh dalam usaha mencapai tujuan karena sangat berperan penting dalam pembentukan kedisiplinan, komitmen pegawai dan kinerja pegawai, sehingga dapat dikatakan kepuasan kerja yang tinggi dapat meningkatkan komitmen pegawai (Akhigbe et al., 2014). Lin \& Ching (2015), pada penelitian sebelumnya menunjukkan bahwa komitmen organisasi memiliki pengaruh positif yang signifikan terhadap Organizational Citizenship Behaviour (OCB) dan kepuasan kerja memiliki efek moderat positif yang signifikan pada hubungan antara komitmen organisasi dan Organizational Citizenship Behaviour (OCB).

$\mathrm{H}_{3}$ : Kepuasan Kerja Berpengaruh Positif dan Signifikan sebagai Variabel Moderasi Komitmen Organisasi terhadap Organizational Citizenship Behaviour (OCB)

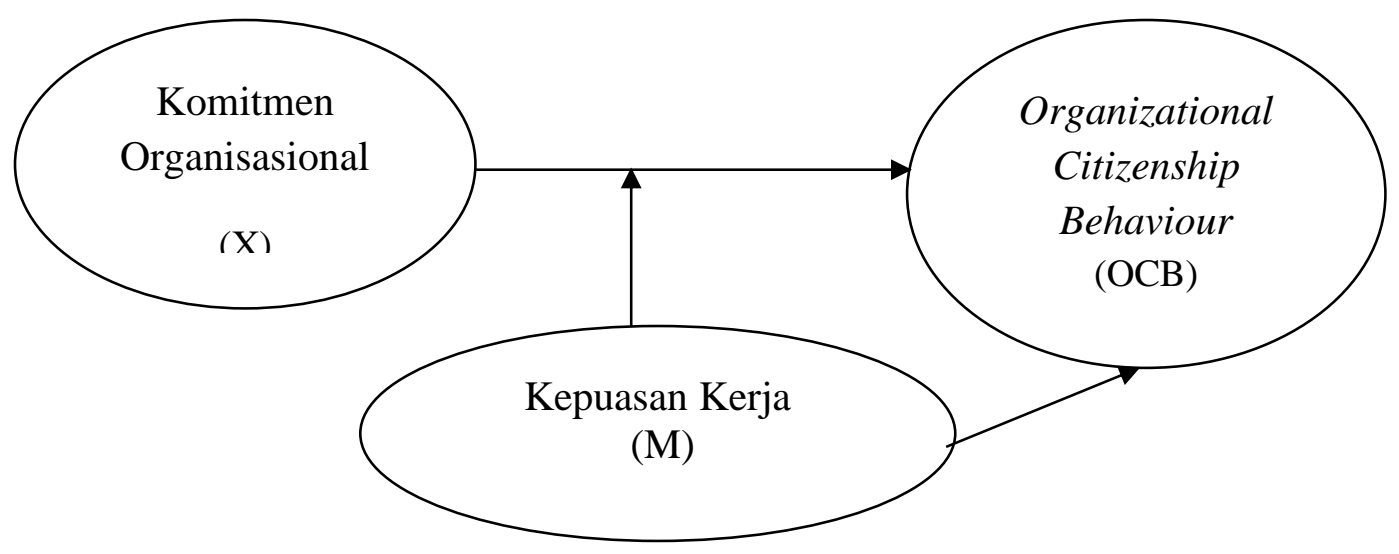

Gambar 1. Kerangka Konseptual

Sumber: Data Penelitian, 2020

\section{METODE PENELITIAN}

Pendekatan yang digunakan dalam penelitian ini adalah pendekatan kuantitatif yang berbentuk asosiatif, dengan tujuan mengetahui pengaruh sebab akibat dari variabel-variabel yang diteliti. Variabel dalam penelitian ini terdiri dari variabel bebas, variabel moderasi dan variabel terikat. Variabel bebas adalah komitmen organisasional (X), variabel moderasi adalah Kepuasan Kerja (Z), dan variabel terikat adalah Organization Citizenship Behaviour (OCB) (Y). Penelitian ini dilakukan di Dinas Sosial Kota Denpasar di Jalan Mulawarman No. 2 Denpasar. Lokasi tersebut dipilih sebagai lokasi penelitian karena ditemukan masalah-masalah yang menyangkut komitmen organisasional, kepuasan kerja dan 
Organizational Citizenship Behaviour (OCB). Objek penelitian ini adalah Organizational Citizenship Behaviour (OCB), komitmen organisasional dan kepuasan kerja pada Dinas Sosial Kota Denpasar.

Organ et al. (2006) menguraikan lima indikator dari OCB, yaitu Altruism adalah tindakan suka rela yang dilakukan oleh pegawai Dinas Sosial Kota Denpasar untuk menolong rekan kerja yang mengalami kesulitan dalam organisasi tanpa ada paksaan atau imbalan apapun. Civic virtue adalah perilaku yang menunjukan bahwa pegawai Dinas Sosial Kota Denpasar melakukan pastisipasi secara sukarela terhadap kegiatan dalam organisasi. Conscientiousness adalah perilaku pegawai Dinas Sosial Kota Denpasar yang ingin untuk melakukan pekerjaan melebihi dari standar pencapaian. Courtesy adalah perilaku meringankan masalah-masalah yang berkaitan dengan pekerjaan yang di hadapi sesama pegawai Dinas Sosial Kota Denpasar. Sportmanship, adalah pantanganpantangan membuat isu yang dapat menjatuhkan pegawai Dinas Sosial Kota Denpasar yang lain.

Dimensi dari kepuasan kerja menurut Luthans (2006) yaitu Pekerjaan itu sendiri, merupakan pekerjaan yang dapat diselesaikan oleh pegawai Dinas Sosial Kota Denpasar itu sendiri. Kedua, gaji yang merupakan sejumlah pemberian imbalan terhadap hasil kerja pegawai Dinas Sosial Kota Denpasar. Ketiga, kesempatan promosi, merupakan kesempatan bagi pegawai Dinas Sosial Kota Denpasar untuk terus maju dan berkembang sebagai bentuk pengembangan diri. Keempat, pengawas merupakan kemampuan pimpinan untuk menunjukkan perhatian dan memberikan bantuan kapada pegawai Dinas Sosial Kota Denpasar saat mereka mengalami kesulitan kerja. Kelima, Rekan kerja, merupakan sejauh mana pegawai Dinas Sosial Kota Denpasar bisa menjalin persahabatan dan saling mendukung di dalam lingkungan kerja. Meyer \& Allen (1991) menjelaskan terdapat tiga dimensi komitmen organisasional, yaitu komitmen afektif, komitmen berkelanjutan dan komitmen normatif.

Populasi adalah wilayah generalisasi yang terdiri atas objek dan subyek yang mempunyai kualitas dan karakteristik tertentu yang ditetapkan oleh peneliti untuk dipelajari dan kemudian ditarik kesimpulannya (Sugiyono, 2017:80). Sedangkan ukuran populasi adalah banyaknya objek psikologis yang menjadi anggota sebuah populasi, menyimak pemahaman tersebut maka populasi pada penelitian ini adalah 127 orang pegawai yang ada pada Dinas Sosial Kota Denpasar. Perhitungan jumlah sampel dalam peneltian ini adalah sebagai berikut.

$$
\begin{aligned}
& n=\mathrm{N} / 1+\mathrm{Ne}^{2} \ldots \ldots \ldots \ldots \ldots \ldots \ldots \ldots \ldots \ldots \ldots \ldots \ldots \ldots \ldots \ldots \ldots \\
& n=127 / 1+127(0,05)^{2} \\
& n=96 \text { pegawai Dinas Sosial Kota Denpasar }
\end{aligned}
$$

Berdasarkan rumus Slovin jumlah sampel yang didapat 96 responden seperti yang tertera pada Tabel 3 . 
Tabel 3.

Populasi dan Sampel

\begin{tabular}{lcc}
\hline \multicolumn{1}{c}{ Bidang } & Jumlah (Orang) & Sampel (Orang) \\
\hline Sekretariat & 38 & 29 \\
Daya Sosial & 27 & 20 \\
Rehabilitas Sosial & 25 & 19 \\
Bina Program & 16 & 12 \\
LIMJAMSOS & 14 & 11 \\
Umum & 7 & 5 \\
Total & $\mathbf{1 2 7}$ & $\mathbf{9 6}$ \\
\hline
\end{tabular}

Sumber: Data Diolah, 2020

Teknik analisis data yang digunakan dalam penelitian ini adalah Moderated Regression Analysis (MRA). Teknik ini bertujuan untuk memberikan dasar untuk mengontrol pengaruh variabel pemoderasi Ghozali, (2013)

Persamaan rumus Moderated Regression Analysis (MRA) untuk menguji hipotesis atau model matematis hubungan variabel moderasi adalah sebagai berikut.

$$
Y_{i}=\alpha+\beta_{1} X_{i}+\beta_{2} Z_{i}+\beta_{3} X_{i}^{\prime} * Z_{i}+\varepsilon
$$

Dengan:

$\mathrm{Y}_{\mathrm{i}} \quad$ Organizational Citizenship Behaviour (OCB)

$\alpha \quad$ : Konstanta

$\beta_{1} \beta_{2} \beta_{3} \quad$ : Koefisien regresi

$X_{i} \quad:$ Komitmen Organisasional

$\mathrm{Z}_{\mathrm{i}} \quad:$ Kepuasan Kerja

$\varepsilon \quad$ : Kesalahan atau standard eror

\section{HASIL DAN PEMBAHASAN}

Responden penelitian ini adalah seluruh pegawai di Dinas Sosial Kota Denpasar. Kuesioner yang disebar dalam penelitian ini sebanyak 86 kuesioner, dalam penyebaran kuesioner ini sebanyak 96 kuesioner kembali. Karakteristik responden dalam penelitian ini merupakan profil dari 96 responden yang berpartisipasi dalam pengisian kuesioner. Profil responden yang terdapat dalam kuesioner terdiri dari jenis kelamin, usia, pendidikan terakhir, serta masa kerja selama berada di dalam perusahaan.

Data responden yang diperoleh dari hasil kuesioner yang telah disebar berdasarkan jenis kelamin dipaparkan dalam Tabel 4.

Tabel 4.

Distribusi Responden Berdasarkan Gender

\begin{tabular}{ccc}
\hline Jenis Kelamin & Jumlah Responden (orang) & Persentase (\%) \\
\hline Laki-laki & 48 & 50 \\
Perempuan & 48 & 50 \\
Total & 96 & 100 \\
\hline
\end{tabular}

Sumber: Data Diolah, 2020 
Tabel 4. menunjukkan bahwa jumlah laki-laki sebanyak 48 orang dengan persentase 50 persen dan jumlah perempuan sebanyak 48 orang dengan persentase 50 persen. Data responden yang diperoleh dari hasil kuesioner yang telah disebar berdasarkan usia dipaparkan dalam Tabel 5 .

Tabel 5. menunjukkan bahwa responden yang berusia antara 18-23 tahun adalah sebanyak 16 orang dengan persentase 16,7 persen. Responden yang berusia 24-29 tahun adalah sebanyak 40 orang dengan persentase 41,7 persen. Responden yang bersusia 30-35 tahun adalah sebanyak 10 orang dengan persentase 10,4 persen. Responden 36-41 tahun adalah sebanyak 7 orang dengan persentase 7,3 persen. Responden yang berusia $\geq 41$ sebanyak 23 orang dengan persentase 24 persen. Hal tersebut menunjukkan bahwa pegawai pada Dinas Sosial Kota Denpasar yang menjadi responden dalam penelitian ini dominan berusia antara 24-29 tahun, hal ini menunjukkan bahwa pegawai yang bekerja pada Dinas Sosial Kota Denpasar tergolong pegawai yang berusia produktif.

Tabel 5.

Distribusi Responden Berdasarkan Usia

\begin{tabular}{ccc}
\hline Usia (tahun) & Jumlah Responden (orang) & Persentase (\%) \\
\hline $18-23$ & 16 & 16,7 \\
$24-29$ & 40 & 41,7 \\
$30-35$ & 10 & 10,4 \\
$36-41$ & 7 & 7,3 \\
$\geq 41$ & 23 & 24,0 \\
Total & 96 & 100 \\
\hline
\end{tabular}

Sumber: Data Diolah, 2020

Data responden yang diperoleh dari hasil kuesioner yang telah disebar berdasarkan pendidikan terakhir dipaparkan dalam Tabel 6.

Tabel 6.

Distribusi Responden Berdasarkan Pendidikan Terakhir

\begin{tabular}{ccc}
\hline Pendidikan Terakhir & Jumlah Responden (orang) & Persentase (\%) \\
\hline SMP & 1 & 1,0 \\
SMA/K & 19 & 19,8 \\
Diploma & 9 & 9,4 \\
S1 & 67 & 69,8 \\
Total & 101 & 100 \\
\hline
\end{tabular}

Sumber: Data Diolah, 2020

Tabel 6. menunjukkan bahwa responden yang menempuh pendidikan terakhir SMP adalah sebanyak 1 orang dengan persentase 1 persen SMA/SMK sederajat adalah sebanyak 19 orang dengan persentase 19,8 persen. Responden yang menempuh pendidikan terakhir diploma adalah sebanyak 9 orang dengan persentase 9,4 persen, sedangkan responden yang menempuh pendidikan terakhir S1 adalah sebanyak 67 orang dengan persentase 69,8 persen. Hal tersebut menunjukkan bahwa pegawai Dinas Sosial Kota Denpasar yang menjadi responden dalam penelitian ini dominan menempuh pendidikan terakhir $\mathrm{S} 1$, hal 
ini menunjukkan bahwa pegawai Dinas Sosial Kota Denpasar merupakan pegawai yang berpendidikan. Data responden yang diperoleh dari hasil kuesioner yang telah disebar berdasarkan jenis kelamin dipaparkan dalam Tabel 7.

Tabel 7.

Distribusi Responden Berdasarkan Masa Kerja

\begin{tabular}{ccc}
\hline Masa Kerja (tahun) & Jumlah Responden (orang) & Persentase (\%) \\
\hline$<3$ & 42 & 43,8 \\
$3-5$ & 24 & 21,9 \\
$6-8$ & 30 & 31,3 \\
$9-11$ & 2 & 2,1 \\
$>11$ & 1 & 1,0 \\
Total & 96 & 100 \\
\hline
\end{tabular}

Sumber: Data Diolah, 2020

Tabel 7. menunjukkan bahwa responden yang memiliki masa kerja $<3$ tahun adalah sebanyak 42 orang dengan persentase 43,8 persen. Responden yang memiliki masa kerja antara 3 sampai 5 tahun adalah sebanyak 24 orang dengan persentase 21,9 persen, sedangkan responden yang memiliki masa kerja antara 6-8 tahun adalah sebanyak 30 orang dengan persentase 31,3 persen, responden yang memiliki masa kerja antara 9-11 tahun adalah sebanyak 2 orang dengan persentase 2,1 persen dan responden yang memiliki masa kerja lebih dari 11 tahun adalah sebanyak 1 orang dengan persentase 1,0 persen Hal ini menunjukkan bahwa masa kerja Pegawai Dinas Sosial Kota Denpasar yang menjadi responden dalam penelitian ini dominan pegawai yang memiliki masa kerja $<3$ tahun.

Pengujian validitas dilakukan dengan menghitung korelasi antara skor masing-masing butir pernyataan dengan skor total sehingga didapat Pearson Correlation.

Tabel 8.

Hasil Uji Validitas Instrumen

\begin{tabular}{lcccc}
\hline \multicolumn{1}{c}{ Variabel } & Indikator & $\begin{array}{c}\text { Koefisien } \\
\text { Korelasi }\end{array}$ & Sig. (2-tailed) & Keterangan \\
\hline Komitmen & $\left(\mathrm{X}_{1.1}\right)$ & 0,817 & 0,000 & Valid \\
Organisasional & $\mathrm{X}_{1.2}$ & 0,932 & 0,000 & Valid \\
$(\mathrm{X})$ & $\mathrm{X}_{1.3}$ & 0,923 & 0,000 & Valid \\
Kepuasan Kerja & $\left(\mathrm{M}_{1.1}\right)$ & 0,766 & 0,000 & Valid \\
$(\mathrm{M})$ & $\left(\mathrm{M}_{1.2}\right)$ & 0,737 & 0,000 & Valid \\
& $\left(\mathrm{M}_{1.3}\right)$ & 0,866 & 0,000 & Valid \\
& $\left(\mathrm{M}_{1.4}\right)$ & 0,894 & 0,000 & Valid \\
Organizational & $\left(\mathrm{M}_{1.5}\right)$ & 0,897 & 0,000 & Valid \\
Citizenship & $\left(\mathrm{Y}_{1.1}\right)$ & 0,870 & 0,000 & Valid \\
Behaviour $(\mathrm{Y})$ & $\left(\mathrm{Y}_{1.2}\right)$ & 0,843 & 0,000 & Valid \\
& $\left(\mathrm{Y}_{1.3}\right)$ & 0,882 & 0,000 & Valid \\
& $\left(\mathrm{Y}_{1.4}\right)$ & 0,846 & 0,000 & Valid \\
& $\left(\mathrm{Y}_{1.5}\right)$ & 0,785 & 0,000 & Valid \\
\hline
\end{tabular}

Sumber: Data Diolah, 2020 
Hasil uji validitas pada Tabel 8. menunjukkan bahwa indikator penelitian yang digunakan untuk mengukur variabel komitmen organisasional dan Organizational Citizenship Behaviour $(Y)$ memiliki nilai koefisien korelasi dengan skor total seluruh butir pernyataan lebih besar dari 0,30 dengan signifikansi kurang dari 0,05 . Hasil ini valid dan layak digunakan sebagai instrumen penelitian. Hasil pengujian reliabilitas instrumen disajikan pada Tabel 9.

Tabel 9.

Hasil Reliabilitas Instrumen

\begin{tabular}{lcc}
\hline Variabel & Cronbach's Alpha & Keterangan \\
\hline Komitmen Organisasional (X) & 0,859 & Reliabel \\
Kepuasan Keja (M) & 0,886 & Reliabel \\
Organizational Citizenship Behaviour & 0,898 & Reliabel \\
$(Y)$ & & \\
Sumber: Data Diolah, 2020 & &
\end{tabular}

Hasil uji reliabilitas pada Tabel 9. menunjukkan bahwa variabel penelitian memiliki koefisien Cronbach's Alpha lebih dari 0,30. Jadi dapat dinyatakan bahwa seluruh variabel telah memenuhi syarat reliabilitas atau kehandalan sehingga dapat digunakan untuk dianalisis lebih lanjut.

Uji asumsi klasik meliputi uji normalitas, uji auto korelasi, dan uji heterokedastisitas. Masing-masing uji asumsi klasik akan dijabarkan sebagai berikut. Uji normalitas bertujuan untuk menguji apakah dalam model regresi, variabel pengganggu atau residual memiliki distribusi normal atau tidak. Model regresi yang baik adalah memiliki distribusi normal atau mendekati normal (Ghozali, 2012). Untuk mendeteksi normalitas data digunakan uji KolmogorovSmirnov. Hasil uji normalitas untuk seluruh sampel dapat dilihat pada Tabel 10.

Tabel 10. Hasil Uji Normalitas

\begin{tabular}{llr}
\hline & & Unstandardized Residual \\
\hline $\mathrm{N}$ & & 96 \\
Normal Parameters & Mean & -.0040109 \\
& Std.Deviation & .24698476 \\
Most Extreme Differences & Absolute & .110 \\
& Positive & .110 \\
& Negative & -.090 \\
Kolmogorov-Smirnov Z & & 1,081 \\
Asymp. Sig. (2-tailed) & & .193 \\
\hline Sumber:
\end{tabular}

Tabel 10. menunjukkan hasil uji normalitas dengan uji KolmogrorovSmirnov pada analisis regresi moderasi menunjukkan nilai Asymp.Sig (2-tailed) 0.196 lebih besar dari level of significant, yaitu 5 persen $(\alpha=0,05)$, sehingga data yang diuji menyebar normal atau berdistribusi normal.

Uji Multikolinearitas bertujuan untuk menguji apakah dalam model regresi ditemukan adanya korelasi antar variabel bebas dalam model regresi (Ghozali, 2012). Model regresi yang baik seharusnya bebas dari multikolinearitas. Deteksi 
terhadap ada atau tidaknya multikolinearitas yaitu (a) nilai R square (R2) yang dihasilkan oleh suatu estimasi model regresi empiris yang sangat tinggi, tetapi secara individual tidak terikat, (b) menganalisis matriks variabel-variabel eindependen. Jika antara variabel independen terdapat indikasi yang tinggi (yang lebih dari 0,009), maka merupakan indikasi adanya multikolineritas. (c) melihat tolerance dan VIF, suatu model regresi yang bebas dari masalah multikolinearitas apabila mempunyai nilai tolerance dari 0,1 dan nilai VIF > 10 (Ghozali, 2013:106). Hasil uji multikolinieritas penelitian dapat dilihat pada Tabel 11.

Tabel 11.

\section{Hasil Uji Multikolinieritas}

\begin{tabular}{lcc}
\hline \multicolumn{1}{c}{ Variabel } & Tolerance & VIF \\
\hline Komitmen Organisasional & 0,397 & 2,516 \\
Kepuasan Kerja & 0,397 & 2,521 \\
Interaksi antara komitmen organisasional dan kepuasan & 0,993 & 1,007 \\
kerja & & \\
\hline
\end{tabular}

Sumber: Data Diolah, 2020

Berdasarkan Tabel 11. Dapat dilihat bahwa nilai tolerance pada masingmasing variabel lebih besar dari 10 persen $(0,1)$, demikian pula dengan nilai VIF masing- masing variabel yang lebih kecil dari 10. Hal ini menandakan bahwa pada persamaan regresi linier berganda dengan variabel terikat OCB ini tidak terdapat korelasi antar variabel bebas sehingga persamaan ini bebas dari gejala multikolinearitas.

Uji heteroskedastisitas bertujuan untu menguji apakah dalam sebuah model regresi terjadi ketidaksamaan varians dari resiudal satu pengamatan ke pengamatan yang lain. Model regresi yang baik adalah yang homoskedastisitas atau tidak terjadi heteroskedastisitas (Ghozali, 2012). Untuk melihat ada atau tidaknya heteroskedastisitas dalam suatu varian error term (et) suatu model regresi adalah dengan menggunakan metode uji glejser. Suatu model dikatakan baik jika tidak terjadi heteroskedastisitas. Jika nilai signifikansinya lebih kecil dari 5 persen $(\alpha=0,05)$ maka pada varian terdapat heteroskedastisitas. Jika nilai signifikansinya lebih besar dari 5 persen $(\alpha=0,05)$ maka pada varian tidak terdapat heteroskedastisitas. Hasil uji Glejser dapat dilihat pada Tabel 12.

Tabel 12.

Hasil Uji Heteroskedastisitas

\begin{tabular}{llc}
\hline \multicolumn{1}{c}{ Persamaan } & \multicolumn{1}{c}{ Variabel } & Sig. \\
\hline $\mathrm{Y}=\alpha+\beta_{1} \mathrm{X}+\beta_{2} \mathrm{M}+\beta_{3} \mathrm{X} . \mathrm{M}+$ & Komitmen Organisasional $(\mathrm{X})$ & 0,054 \\
$\mathrm{e}$ & Kepuasan Kerja $(\mathrm{M})$ & 0,399 \\
& Interaksi antara Komitmen Organisasional & 0.226 \\
& dengan Kepuasan Kerja (X.M) & \\
\hline
\end{tabular}

Sumber: Data Diolah, 2020

Tabel 12. menunjukkan bahwa nilai signifikansi komitmen organisasional (X) sebesar 0,054, kepuasan kerja (M) sebesar 0.399, dan interaksi antara komitmen organisasional dengan kepuasan kerja (X.M) sebesar 0,226. Hasil uji 
tersebut memiliki nilai signifikansinya yang lebih besar dari $(\alpha) 0,05$. Oleh karena itu, dapat disimpulkan bahwa tidak terjadi heteroskedastisitas. Hasil uji koefisien determinasi $\left(\mathrm{R}^{2}\right)$ ditunjukkan pada Tabel 13.

Tabel 13.

Hasil Uji Koefisen Determinasi $\left(\mathbf{R}^{2}\right)$

\begin{tabular}{ccccc}
\hline Model & $\mathbf{R}$ & R Square & $\begin{array}{c}\text { Adjusted R } \\
\text { Square }\end{array}$ & $\begin{array}{c}\text { Std. Error of } \\
\text { The Estimate }\end{array}$ \\
\hline 1 & $0.928^{\mathrm{a}}$ & 0,862 & 0,857 & 0.25456 \\
\hline
\end{tabular}

Sumber: Data Diolah, 2020

Koefisien determinasi digunakan untuk mengukur seberapa jauh kemampuan model dalam menjelaskan variabel-variabel dependen. Nilai koefisien determinasi adalah antara nol sampai satu $\left(0<\mathrm{R}^{2}<1\right)$. Apabila $\mathrm{R}^{2}$ sama dengan 1 , berarti 100 persen total variabel terikat dapat dijelaskan oleh variabel bebasnya sehingga menunjukkan ketepatan terbaik. Apabila nilai $\mathrm{R}^{2}$ sama dengan 0 , berarti tidak ada variasi variabel terikat yang dapat dijelaskan oleh variabel bebasnya. Peneliti menggunakan nilai adjusted $\mathrm{R}^{2}$ pada saat mengevaluasi yang mana model regresi terbaik, karena tidak seperti $\mathrm{R}^{2}$, nilai adjusted $\mathrm{R}^{2}$ (koefisien determinasi yang telah disesuaikan) dapat naik atau turun apabila satu variabel independen ditambahkan ke dalam model. Hasil uji koefisen determinasi dalam Tabel 13. menunjukkan besarnya nilai adjusted $\mathrm{R}^{2}$ adalah sebesar 0,857 . Ini berarti variasi OCB dapat dipengaruhi secara signifikan oleh variabel komitmen organisasional, kepuasan kerja, dan variabel interaksi antara komitmen organisasional dan kepuasan kerja sebesar 85,7 persen sedangkan sisanya sebesar 14,3 persen dijelaskan oleh faktor-faktor lain.

Kelayakan model (Uji F) yang menunjukkan bahwa model atau persamaan regresi yang telah dibuat layak untuk diteliti. Kelayakan suatu model dilihat dari nilai probabilitas signifikansinya, yaitu jika nilai probabilitas signifikansinya lebih kecil dari tingkat signifikansi $(\alpha)$ 0,05 (sig. $<(\alpha)$ 0,05), maka $\mathrm{H}_{0}$ ditolak dan $\mathrm{H}_{1}$ diterima. Jika nilai probabilitas signifikansi lebih besar dari tingkat signifikansi $(\alpha)$ 0,05 (sig. > $(\alpha)$ 0,05), maka $\mathrm{H}_{0}$ diterima dan $\mathrm{H}_{1}$ ditolak. Hasil uji kesesuaian model (Uji F) ditunjukkan pada Tabel 14.

Tabel 14.

Hasil Uji Kesesuaian Model (Uji F)

\begin{tabular}{llccccc}
\hline & Model & $\begin{array}{c}\text { Sum of } \\
\text { Squares }\end{array}$ & df & $\begin{array}{c}\text { Mean } \\
\text { Square }\end{array}$ & F & Sig. \\
\hline 1 & Regression & 37,121 & 3 & 12,374 & 190,949 & $.000^{\mathrm{a}}$ \\
& Residual & 5,962 & 92 & 0,65 & & \\
& Total & 43,082 & 95 & & & \\
\hline
\end{tabular}

Sumber: Data Diolah, 2020

Oleh karena signifikansi $\mathrm{F}_{\text {hitung }}$ sebesar $0,000<0,05$ maka $\mathrm{H}_{0}$ ditolak, ini berarti komitmen organisasional dan kepuasan kerja berpengaruh signifikan secara bersama-sama terhadap kepuasan kerja. Uji t digunakan untuk mengetahui apakah suatu variabel bebas secara individu berpengaruh terhadap variabel 
terikatnya. Kriteria pengujian untuk menjelaskan interpretasi pengaruh antar masing-masing variabel yakni jika nilai signifikansi $<(\alpha) 0,05$ maka $\mathrm{H}_{0}$ ditolak dan $\mathrm{H}_{1}$ diterima. Sebaliknya, jika nilai signifikansi $>(\alpha) 0,05$ maka $\mathrm{H}_{0}$ diterima dan $\mathrm{H}_{1}$ ditolak. Hasil analisis regresi moderasi dalam penelitian ini ditunjukan pada Tabel 15.

Tabel 15.

Hasil Uji Siginifikasi Parsial (Uji T)

\begin{tabular}{lcc}
\hline \multicolumn{1}{c}{ Model } & t & Sig. \\
\hline Komitmen Organisasional & 2,843 & 0,006 \\
Kepuasan Kerja & 12,770 & 0,000 \\
Interaksi antara komitmen & 3,779 & 0,000 \\
organisasional dan kepuasan kerja & & \\
\hline
\end{tabular}

Sumber: Data Diolah, 2020

Berdasarkan hasil uji t pada Tabel 15. Menunjukan bahwa t hitung variabel komitmen organisasional sebesar 2,843 dengan nilai signifikansi 0,006 yang lebih kecil dari $\alpha=0,05$, ini berarti bahwa variabel komitmen organisasional berpengaruh signifikan terhadap OCB. Demikian juga pada variabel kepuasan kerja menunjukan nilai $t$ hitung sebesar 12,770 dengan signifikansi 0,000 yang lebih kecil dari $\alpha=0,05$ menandakan bahwa variabel kepuasan kerja berpengaruh signifikan terhadap OCB pada pegawai Dinas Sosial Kota Denpasar.

Moderated Regression Analysis (MRA) digunakan untuk mengetahui pengaruh kepuasan kerja $(\mathrm{M})$ dalam memoderasi komitmen organisasional (X) terhadap OCB (Y). Hasil pengujian Moderated Regression Analysis (MRA) Ditunjukan pada Tabel 16.

Hasil analisis regresi moderasi seperti yang disajikan pada Tabel 16. maka persamaan strukturalnya adalah sebagai berikut.

$$
\begin{aligned}
& \mathrm{Y}=\alpha+\beta_{1} \mathrm{X}+\beta_{2} \mathrm{M}+\beta_{3} \mathrm{XM}+\mathrm{e} \ldots \ldots \ldots \ldots \ldots \\
& \mathrm{Y}=3,970+0,118 \mathrm{X}+0,530 \mathrm{M}+0,0211 \mathrm{XM}
\end{aligned}
$$

Persamaan regresi dapat menjelaskan bahwa nilai koefisien moderasi $\left(\beta_{2}\right)$ signifikan, maka kepuasan kerja (M) merupakan variabel moderasi. Koefisien variabel komitmen organisasional (X) bertanda positif 0,118 signifikan dan koefisien variabel Kepuasan Kerja (M) bertanda positif 0,530 signifikan, sehingga variabel moderasi memperkuat pengaruh variabel komitmen organisasional (X) terhadap variabel Organizational Citizenship Behaviour (OCB).

Hasil uji analisis regresi, menunjukkan bahwa hasil analisis pengaruh komitmen organisasional terhadap Organizational Citizenship Behaviour (OCB) diperoleh nilai signifikansi sebesar 0,006 dengan nilai koefisien beta 0,118. Nilai signifikansi $0,006^{\mathrm{a}}<(\alpha)$ 0,05 mengindikasikan bahwa $\mathrm{H}_{0}$ ditolak dan $\mathrm{H}_{1}$ diterima. Hasil ini mempunyai arti bahwa komitmen organisasional berpengaruh positif dan signifikan terhadap perilaku Organizational Citizenship Behaviour (OCB) pegawai Dinas Sosial Kota Denpasar. Dengan demikian, semakin tinggi tingkat komitmen organisasional pada pegawai, perilaku Organizational Citizenship Behaviour (OCB) pada pegawai Dinas Sosial Kota Denpasar juga semakin tinggi. 
Tabel 16.

Hasil MRA (Moderated Regression Analysis)

\begin{tabular}{|c|c|c|c|c|c|}
\hline \multirow[t]{2}{*}{ Model } & \multicolumn{2}{|c|}{$\begin{array}{c}\text { Unstandardized } \\
\text { Coefficients } \\
\end{array}$} & \multirow{2}{*}{$\begin{array}{c}\begin{array}{c}\text { Standardized } \\
\text { Coefficients }\end{array} \\
\text { Beta }\end{array}$} & \multirow[b]{2}{*}{$\mathbf{T}$} & \multirow[b]{2}{*}{ Sig. } \\
\hline & B & $\begin{array}{c}\text { Std. } \\
\text { Error }\end{array}$ & & & \\
\hline 1 (Constant) & 3,970 & 0,037 & & 107,266 & 0,000 \\
\hline $\begin{array}{l}\text { Komitmen } \\
\text { Organisasional (X) }\end{array}$ & 0,118 & 0,041 & 0,175 & 2,843 & 0,006 \\
\hline Kepuasan Kerja (M) & 0,530 & 0,041 & 0,786 & 12,770 & 0,000 \\
\hline $\begin{array}{l}\text { Interaksi antara } \\
\text { komitmen organsional } \\
\text { dengan kepuasan kerja }\end{array}$ & 0,211 & 0,056 & 0,147 & 3,779 & 0,000 \\
\hline R Square & & & & & 0,862 \\
\hline Adjusted R Square & & & & & 0,857 \\
\hline F Hitung & & & & & 190,949 \\
\hline Signifikansi F & & & & & .000 \\
\hline
\end{tabular}

Hasil rangkuman penilaian responden yang disajikan dalam deskripsi variabel penelitian menunjukkan bahwa penelitian responden terhadap komitmen organisaional berada dalam kategori tinggi yang ditandai dengan tanggapan responden mengenai responden merasa bahwa responden merupakan bagian dari Dinas Sosial Kota Denpasar dengan rasa emosional yang tinggi dan merasa sangat beruntung bisa bekerja di Dinas Sosial Kota Denpasar.

Hasil penelitian ini didukung penelitian yang telah dilakukan oleh Bakan et al. (2013), Anshori (2013), Parnell dan Crandal (2003), Feather dan Rauter (2004) menemukan bahwa adanya hubungan antara komitmen organisasional dengan Organizational Citizenship Behaviour (OCB) pegawai dengan komitmen organisasional yang tinggi cenderung menunjukkan Organizational Citizenship Behaviour (OCB).

Hasil uji analisis regresi, menunjukkan pengaruh kepuasan kerja terhadap Organizational Citizenship Behaviour (OCB). diperoleh nilai signifikansi sebesar 0,000 dengan nilai koefisien beta 0,530 . Nilai signifikansi $0,000^{\mathrm{a}}<(\alpha) 0,05$ mengindikasikan bahwa $\mathrm{H}_{0}$ ditolak dan $\mathrm{H}_{1}$ diterima. Hasil ini mempunyai arti bahwa kepuasan kerja berpengaruh positif dan signifikan terhadap perilaku Organizational Citizenship Behaviour (OCB). Pegawai Dinas Sosial Kota Denpasar. Dengan demikian, semakin tinggi tingkat kepuasan kerja pada pegawai, maka perilaku Organizational Citizenship Behaviour (OCB) pada pegawai Dinas Sosial Kota Denpasar juga akan semakin tinggi.

Hasil rangkuman penilaian responden yang disajikan dalam deskripsi variabel penelitian menunjukkan bahwa penelitian responden terhadap kepuasan kerja berada dalam kategori tinggi yang ditandai dengan tanggapan responden bahwa semua pegawai mempunyai kesempatan yang sama untuk maju dan berkembang.

Hasil penelitian ini didukung penelitian yang telah dilakukan oleh Rohayati (2014); Lu et al. (2013); Chiboiwa et al. (2011), bahwa tinggi rendahnya 
Organizational Citizenship Behaviour (OCB) sebagai akibat dari tinggi rendahnya kualitas kepuasan kerja yang berjalan. Hasil yang sama juga ditunjukkan oleh penelitian yang dilakukan oleh Kencanawati (2014) menyatakan bahwa kepuasan kerja berpengaruh signifikan terhadap Organizational Citizenship Behaviour (OCB).

Hasil analisis regresi moderasi pada Tabel 10. menunjukan bahwa hasil analisis pengaruh komimen organisasional terhadap Organizational Citizenship Behaviour (OCB) nilai signifikansi sebesar 0,006 (significant) dengan nilai koefisien regresi sebesar 0,118. Nilai signifikansi variabel moderasi kepuasam kerja pada Organizational Citizenship Behaviour (OCB) $\left(\beta_{2}\right)$ sebesar 0,000 (significant) dengan nilai koefisien beta sebesar 0,530 dan nilai signifikan variabel interaksi antara komitmen organisasional dengan kepuasan kerja pada OCB $\left(\beta_{3}\right)$ sebesar 0,000 dengan nilai koefisien beta sebesar 0,211 (significant), hal ini mengindikasikan variabel moderasi merupakan tipe moderasi semu (quasi moderasi), karena koefisien $\left(\beta_{2}\right)$ significant dan koefisien $\left(\beta_{3}\right)$ significant. Quasi moderasi merupakan variabel yang memoderasi hubungan antara variabel dependen dan variabel independen di mana variabel moderasi semu berinteraksi dengan variabel dependen sekaligus menjadi variabel dependen.

Hasil analisis regresi moderasi menunjukkan bahwa nilai koefisien regresi $\beta_{3}$ signifikansinya $0,000<0,05$ (signifikan), berarti kepuasan kerja merupakan variabel moderasi, karena nilai koefisien regresi $\beta_{3}$ signifikan, selanjutnya dilacak apakah memperkuat atau memperlemah pengaruh komitmen organisasional terhadap Organizational Citizenship Behaviour (OCB). Hasil uji ditemukan bahwa $\beta_{1}$ positif dan $\beta_{3}$ positif signifikan, maka kepuasan kerja sebagai variabel moderasi yang memperkuat pengaruh komitmen organisasional terhadap Organizational Citizenship Behaviour (OCB) pada Dinas Sosial Kota Denpaar. Hal ini mengindikasikan bahwa hubungan positif komitmen organisasional terhadap perilaku OCB pada pegawai Dinas Sosial Kota Denpasar akan memperkuat saat individu memiliki kepuasan kerja yang tinggi.

Hasil penelitian ini didukung penelitian yang telah dilakukan oleh (Kuehn \& Al-Busaidi (2002); Akhigbe et al., (2014); Lin \& Ching, (2015), Kepuasan kerja memiliki pengaruh dalam usaha mencapai tujuan karena sangat berperan penting dalam pembentukan kedisiplinan, komitmen pegawai dan kinerja pegawai, sehingga dapat dikatakan kepuasan kerja yang tinggi dapat meningkatkan komitmen pada pegawai selain itu komitmen organisasi memiliki pengaruh positif yang signifikan terhadap Organizational Citizenship Behaviour (OCB) dan kepuasan kerja memiliki efek moderat positif yang signifikan pada hubungan antara komitmen organisasi dan Organizational Citizenship Behaviour (OCB).

Hasil penelitian ini memberikan sebuah implikasi teoritis bagaimana pentingnya komitmen organisasional dan kepuasan kerja dapat mempengaruhi Organizational Citizenship Behaviour (OCB). Hasil yang diperoleh dalam penelitian ini menunjukkan bahwa komitmen organisasional berpengaruh positif dan signifikan terhadap Organizational Citizenship Behaviour (OCB) pada pegawai Dinas Sosial Kota Denpasar. Dengan demikian, semakin tinggi 
komitmen organisaional pada pegawai maka perilaku Organizational Citizenship Behaviour (OCB) pada pegawai akan meningkat. Hasil selanjutnya yaitu kepuasan kerja berpengaruh positif dan signifikan terhadap Organizational Citizenship Behaviour (OCB) pegawai Dinas Sosial Kota Denpasar. Dengan demikian, semakin tinggi rasa kepuasan kerja pada pegawai maka perilaku Organizational Citizenship Behaviour (OCB) pada pegawai akan meningkat pula. Hasil yang selanjutnya yaitu variabel kepuasan kerja merupakan variabel moderasi yang memperkuat pengaruh komitmen organisasional terhadap Organizational Citizenship Behaviour (OCB) pegawai Dinas Sosial Kota Denpasar. Kepuasan kerja dapat membantu meningkatkan perilaku Organizational Citizenship Behaviour (OCB) dan komitmen organisasional yang dirasakan karyawan. Implikasi penelitian ini dapat menggambarkan bahwa antara variabel komitmen organisasional, Organizational Citizenship Behaviour (OCB) dan kepuasan kerja saling berkaitan.

Patut disadari bahwa terdapat beberapa keterbatasan dalam penelitian ini yaitu penelitian ini menggunakan kuisioner yang disebarkan melalui pegawai di bidang kepegawaian Dinas Sosial Kota Denpasar sehingga peneliti tidak dapat mendampingi secara langsung proses pengisian kuesioner sehingga tidak bisa melakukan crosscheck terkait jawaban responden kepada atasannya. Variabelvariabel yang digunakan pada penelitian ini hanya terbatas yaitu meneliti tiga variabel mengenai kepuasan kerja, komitmen organisasional, dan Organizational Citizenship Behaviour (OCB). Penelitian selanjutnya diharapkan untuk dapat menambah variabel lain yang juga mampu mempengaruhi variabel Organizational Citizenship Behaviour (OCB).

\section{SIMPULAN}

Komitmen organisasional berpengaruh positif dan signifikan terhadap OCB yang berarti bahwa, pegawai yang memiliki komitmen organisasional yang tinggi akan menimbulkan perilaku OCB yang semakin tinggi. Kepuasan kerja berpengaruh positif dan signifikan terhadap OCB yang berarti bahwa, pegawai yang memiliki kepuasan kerja yang tinggi akan menimbulkan perilaku OCB yang semakin tinggi. Kepuasan kerja memoderasi pengaruh komitmen organisasional terhadap OCB, kepuasan kerja sebagai variabel moderasi memperkuat pengaruh komitmen organisasional terhadap perilaku OCB pegawai Dinas Sosial Kota Denpasar. Kepuasan kerja membantu memperkuat komitmen organisasional yang dirasakan pegawai sehingga perilaku OCB pegawai meningkat.

Instansi sebaiknya lebih menanamkan sikap komitmen pada karyawan dengan membangun rasa kebersamaan dan menciptakan suasana kerja yang kondusif dan menyenangkan bagi pegawai, dengan melakukan kegiatan bersama antara seluruh pegawai dapat membangun dan meningkatkan kekompakan sehingga pegawai berkomitmen pada organisasi dan diharapkan pegawai untuk terus bekerja dan tidak merasa dituntut bekerja di Dinas Sosial Kota Denpasar. Hal tersebut perlu dilakukan pula untuk meningkatkan perilaku OCB antar sesama pegawai. Instansi dapat meningkatkan kepuasan kerja para pegawainya dengan 
memberikan gaji sesuai dengan pekerjaan yang dikerjakannya. Hal tersebut perlu dilakukan agar pegawai dapat termotivasi untuk mendapatkan hasil kerja yang lebih baik dan dapat meningkatkan perilaku OCB pada Dinas Sosial Kota Denpasar.

\section{REFERENSI}

Ahdiyana, M. (2013). Dimensi Organizational Citizenship Behaviour (OCB) dalam Kinerja Organisasi. Efisiensi-Kajian Ilmu Administrasi, 10(1), 110 .

Anas, K. (2013). Pengaruh Kompensasi dan Lingkungan Kerja Terhadap Kepuasan Kerja Pegawai PT. Karya Mitra Muda. Jurnal Manajemen, 2(1), hal. 1-11

Andriani, G., Djalali, M. A., \& Sofiah, D. (2012). Organizational Citizenship Behaviour dan Kepuasan Kerja Pada Pegawai. Jurnal Penelitian Psikologi, 3(1), 341-34

Akhigbe, O. J., Felix, O. O., \& Finelady, A. M. (2014). Employee Job Satisfaction and Organizational Commitment in Nigeria Manufacturing Organizations. European Journal of Business and Management, 6(25) 83-95.

Anshori, M. I. (2013). Relasi Komitmen Organisasi dan Kepuasan Kerja terhadap Organizational Citizenship Behaviour (Studi Kasus di Poltekes Surabaya). Jurnal Ilmu Manajemen dan Akuntansi Terapan, 4(1), 42-50.

Aswin, A. E., \& Rahyuda, A. G. (2017). Pengaruh Perceived Organizational Support Terhadap Organizational Citizenship Behaviour Dengan Variabel Kepuasan Kerja Sebagai Mediasi. E-Jurnal Manajemen Unud, 6(5), 2729-2755.

Bandura, A. (1986). Social foundations of tought and action, a social cognitive theory. New Jersey: Prentice-Hall.

Bakan, I., Buyukbese, T., Frsahan, B., \& Kefe, I. (2013). The Effect of Organizational Commitment and Women Employee Organizational Citizenship Behaviour. Indian Journal of Applied Research, 3(2), 202204

Bateman, T. S., \& Organ, D. W. (1983). Job satisfaction and the good soldier: The relationship between affect and employee citizenship. Academy of Management Journal, 26(4), 587-595. 
Chiboiwa, M. W., Chipunza, C., \& Samuel, M. O. (2011). Evaluation of Job Satisfaction and Organisastional Citizenship Behaviour: Case Study of Selected Organisastional in Zimbabwe. African Journal of Business Management, 5(7), 2910-2918.

Erkutlu, H. (2011). The Moderating Role Of Organizational Culture In The Relationship Between Organizational Justice And Organizational Citizenship Behaviours. Leadership and Organization Development Journal, 32(6), 532-554.

Fatimah, A. \& Halim. (2011). The relationship between organizational justice, organizational citizenship behavior and job satisfaction. Pertanika Journal of Social Science \& Humanity, 19(5),115-121

Feather, N. T., \& Rauter, K. A. (2004). Organizational citizenship behaviours in relation to job status, job insecurity, organizational commitment and identification, job satisfaction and work values. Journal of Occupational and Organizational Psychology, 77(1), 81-94.

Ghozali, (2013). Aplikasi Analisis Multivariate Dengan Program SPSS. Ed. Ketujuh. Semarang: Badan Penerbit Universitas Diponegoro

Griffin, R.W. (2004) Management, 7th edition. Massachusetts: Houghton Mifflin Company

Griffin, R.W., \& Ebert, R.J. 1996. Business. Edisi Ke-8 Jilid 1. Jakarta: Prenhallindo.

Harrison, J. K., \& Hubbard, R. (1998). Antecedents to Organizational Commitment among Mexican Employees of a U.S. Firm in Mexico. The Journal of Social Psychology, 138(5), 609-623.

Krietner, R. \& Kinicki, Angelo (2004), Organizational Behaviour, $6^{\text {th }}$ edition, McGrawHill

Kuehn, K. W., \& Al-Busaidi, Y. (2002). Citizenship behaviour in a non-Western context: An examination of the role of satisfaction, commitment and job characteristics on self-reported OCB. International Journal of Commerce \& Management, 12(2), 107-125.

Lin, Chia-Tzu., Chang, Ching-Sheng. (2015). Job Satisfaction of Nurses and Its Moderating Effects on the Relationship Between Organizational Commitment and Organizational Citizenship Behaviour. Research and Theory for Nursing Practice: An International Journal, 29(3), 226-243 
Lovell, S. E., Kahn, A. S., Anton, J., Davidson, A., Dowling, E., Post, D., \& Mason, C. (1999). Does gender affect the link between organizational citizenship behaviour and performance evaluation? A Journal of Research, 41(5/6), 469-478.

Lu, C., Shih, Y. \& Chen, Y. (2013). Effects of Emotional Labor and Job Satisfaction on Organizational Citizenship Behaviors: A Case Study on Business Hotel Chains. International Journal of Organizational Innovation, 5(4), 165-176.

Luthans, F. (2006). Perilaku Organisasi, Edisi Sepuluh. Yogyakarta: Andi

Mischel W, S. Y. (1995). A cognitive-affective system theory of personality: Reconceptualizing situations, dispositions, dynamics, and invariance in personality structure. Psychological Review, 102(2), 246-268.

Meyer, J. P. \& Allen, N. J. (1991). A Three Compo- nent Conceptualization of Organizational Commitment. Human Resource Management Review, 1(1), 61-89.

Nugraha, S. I., \& Adnyani, I. G. A. D. (2018). Pengaruh Budaya Organisasi, Komitmen Organaisasi, dan Kompetensi terhadap Organizational Citizenship Behaviour pada Setda Kota Denpasar. E-Jurnal Manajemen Universitas Udayana, 7(1), 1-28.

O'Reilly, C., \& Chatman, J. (1986). Organizational commitment and psychological attachment: The effects of compliance, identification and internalization on prosocial behaviour. Journal of Applied Psychology, 71(3), 492-499.

Organ, D. W., Podsakoff, P. M. \& MacKenzie, S. B. (2006). Organizational Citizenship Behaviour: Its Nature, Antecedents, and Consequences, SAGE Publications.

Parnell, J. A., \& Crandall, W. (2003). Propensity for participative decisionmaking, job satisfac-tion, organizational commitment, organizational citizenship behaviour, and intentions to leave among Egyptian managers. Multinational Business Review, 11(1), 45-66.

Ping, H., Murmann, S. K. \& Perdue, R. R. (2012). Management commitment and employee perceived service quality: The mediating role of affective Commitment, Journal of Applied Management and Enterpreneurship, 17(3), 79-97. 
Prameswari, S. K. \& Suwandana I. G. M. (2017). Pengaruh Keadilan Organisasional, Komitmen Organisasional, dan Kepuasan Kerja terhadap Organizational Citizenship Behaviour. E-Jurnal Manajemen Universitas Udayana, 6(3), hal. 1368 -1397.

Ratnaningsih, S. Y. (2013). Pengaruh Kepuasan Kerja dan Komitmen Terhadap Organizational Citizenship Behaviour (OCB), Journal Media Mahandhika.

Rivai, Veithzal., \& Sagala, Ella Jauvani. (2011). Manajemen Sumber Daya Manusia untuk Organisasi dari Teori ke Praktik. Jakarta: PT Rajagrafindo Persada.

Robbins, S. P. dan Judge, T. A. (2008). Perilaku Organisasi "Organizational Behaviour". Edisi 12. Jakarta: Salemba Empat

Rohayati, A. (2014). Pengaruh kepuasan kerja terhadap organizational citizenship behavior: Studi Pada Yayasan Masyarakat Madani Indonesia. Study \& Management Research, 11(1), 20-38.

Schappe, S. P. (1998). The influence of job satisfaction, organizational commitment, and fairness perceptions on organizational citizenship behavior. The Journal of Psychology: Interdisciplinary and Applied, 132(3), 277-290

Sharma, J. P., Bajpai, N. \& Holani, U. (2011). Organizational Citizenship Behavior in Public and Private Sector and Its Impact on Job Satisfaction: A Comparative Study In Indian Perspective. International Journal of Business and Management, 6(1), 67-75.

Wiener, Y. (1982). Commitment in Oganizations: A Normative View. Academy Of Management Review, 7(3), 418-428.

Woolfolk, A. (2009). Educational Psychology: Active Learning Edition (Edisi Sepuluh). Yogyakarta: Pustaka Pelajar

Yanti, P. E. T. \& Supartha, W. G. (2017). Pengaruh Komitmen Organisasional Dan Kepuasan Kerja Terhadap Organizational Citizenship Behaviour (OCB). E-Jurnal Manajemen Unud, 6(2), 721-747 